\title{
CHEMOSPHERE
}

\section{Arsenic contaminated site at an abandoned copper smelter plant: waste characterization and solidification/stabilization treatment}

\author{
Chien-Jen Shih *, Cheng-Fang Lin \\ Graduate Institute of Environmental Engineering, National Taiwan University, 71 Chou-Shan Road, Taipei 116, Taiwan
}

Received 10 April 2003; received in revised form 30 April 2003; accepted 30 April 2003

\begin{abstract}
A preliminary survey of an arsenic contaminated site from an abandoned copper smelting facility and feasibility study of using solidification/stabilization (S/S) process to treat the contaminant waste were undertaken. It was found that the waste, located in the three-flue gas discharge tunnels, contained $2-40 \%$ arsenic. The $\mathrm{pH}$ of the contaminated waste is extremely low (ranging from 1.8 to 3.6). The X-ray diffraction evidence indicates that the arsenic particles present in the flue gas mainly exist as $\mathrm{As}(\mathrm{III})$, or $\mathrm{As}_{2} \mathrm{O}_{3}$. The total amount of arsenic contaminated waste is estimated to be 700 ton in the studied area. About $50 \%$ of the particle sizes are less than $2 \mathrm{~mm}$. Arsenic is easily extracted from wastes with a variety of leaching solutions. In order to meet the arsenic leaching standard of the toxicity characteristic leaching procedure (TCLP), an extremely high cement dosage is required in the $\mathrm{S} / \mathrm{S}$ process (cement/waste weight ratio $>6$ ). The waste with lower particle size having higher specific surface area exhibits somewhat positive effect on the $\mathrm{S} / \mathrm{S}$ performance. The use of fly ash from municipal waste incinerators, in conjunction with the reduced amount of cement, is able to meet the TCLP arsenic and lead standards. The use of lime alone could meet the TCLP arsenic standard, but lead leaching concentrations exceeded leaching $\mathrm{Pb}$ standard. The results of semi-dynamic leaching tests of some solidified samples indicate higher accumulated arsenic leaching concentrations after only a few leachant renewals.
\end{abstract}

(c) 2003 Elsevier Ltd. All rights reserved.

Keywords: Arsenic; Solidification/stabilization; TCLP; Copper smelter; Fly ash

\section{Introduction}

Arsenic pollution either in aqueous solutions or in contaminated soils has presented significant environmental concerns. Arsenic is widely used at industrial plants producing pesticides, alloys, electronics, and wood preservatives (Lide, 1994). Arsenic particles are also discharged into atmosphere during copper smelting operation (e.g., Ginocchio, 2000; Barcan, 2002), and

\footnotetext{
${ }^{*}$ Corresponding author. Tel.: +886-919-522-726; fax: +8862-2392-7653.

E-mail address: cjshih@ms2.hinet.net (C.-J. Shih).
}

eventually accumulated in soils, exemplified by the arsenic contamination over a large area in King County, Washington, USA, due to the past copper smelting operation (EHD, 2000). In the environment, arsenic exists in several oxidation states: As(V), arsenate; As(III), arsenite; $\operatorname{As}(0)$, and $\operatorname{As}(-\mathrm{III})$, arsine. The arsenic valence state primarily depends on type and source of arsenic pollutant, environmental $\mathrm{pH}$, oxidation-reduction potential, ligand exchange, the presence of iron oxides and other sulfur-containing compounds, as well as microbial activities (Ferguson and Gavis, 1972; Matera and Hecho, 2001).

In general, As(III) is the most toxic form of arsenic, followed by $\mathrm{As}(\mathrm{V})$, and to a lesser extent, methylated 
arsenic, e.g., $\mathrm{CH}_{3} \mathrm{H}_{2} \mathrm{AsO}_{3}$ (RTI, 1998). Arsenic is classified in the US Environmental Protection Agency (EPA) priority pollutant list with a carcinogenicity classification A (human carcinogen). The $\mathrm{LD}_{50}$ (lethal dose) is estimated to be 1-4 mg As/ $/ \mathrm{kg}$ for adult (Pontius et al., 1994). The known arsenic health problems include skin cancer, the so-called "black-foot" disease in Taiwan where 1056 cases have been reported (Shen, 1973). The US EPA has established a maximum contaminant level for arsenic in drinking water $(0.01 \mathrm{mg} / \mathrm{l})$ by 2006 (Federal Register, 2001). For the contaminated soil cleanup level, the state of Washington, for example, has set a maximum $20 \mathrm{mg}$ arsenic/kg for unrestricted land use and $200 \mathrm{mg} / \mathrm{kg}$ for industrial use (WDE, 2001) and the residential maximum allowable soil concentration is $0.4 \mathrm{mg} / \mathrm{kg}$ (cancer endpoint) in the state of Oregon (Oregon, 1999).

In Taiwan, arsenic pollution presents a significant public concern, due in part to the past scared black-foot cases. The public is justifiably alarmed by the presence of an abandoned copper smelter site located in northern Taiwan. Adverse impacts of copper smelting operation on human health and the environment including effects on workers (Lubin et al., 2000), nearby residents (Hwang et al., 1997; Keegan et al., 2002), sediments (Mariner et al., 1997; Ongley et al., 2002), soils (EHD, 2000; Ongley et al., 2002), and mine tailing (Jones et al., 1997) may result from improper management of smelting operation/wastes, because copper ores contain an abundant arsenic content, e.g., enargite, $\mathrm{Cu}_{3} \mathrm{AsS}_{4}$ (Chen et al., 2003). In fact, a feasibility study was conducted on this abandoned site in 1994 for potential remediation. The study indicates that the solidification/stabilization $(\mathrm{S} / \mathrm{S})$ process would be the best practical technology to treat the arsenic waste (TPC, 1994). The S/S process was also reported by other investigators in treating arsenic contaminated wastes (Artiola et al., 1990; Dutre and Vandecasteele, 1995a; Voigt et al., 1996; Akhter et al., 2000; Miller et al., 2000; Fuessle and Taylor, 2000; Kameswari et al., 2001). The mechanisms of cement chemistry with wastes (pozzolanic reactions) are relatively well established (Conner and Hoeffner, 1998).

The general consensus is that the S/S performance of treating arsenic contaminated wastes depends on the quantity of cement added, type and the amount of additive or binders such as lime, fly ash or iron salts used (Dutre and Vandecasteele, 1995a; Akhter et al., 1997; Fuessle and Taylor, 2000; Kameswari et al., 2001), type of arsenic species present (Akhter et al., 1997, 2000), curing period (e.g., Akhter et al., 1997), and pre-treatment washing of samples (washing, Dutre et al., 1999). In particular, the addition of lime is found to be the most effective in reducing the arsenic leachate concentrations due to the formation of calcium arsenic compound, e.g., $\mathrm{CaHAsO}_{3}$ in the $\mathrm{As}(\mathrm{III})$-containing wastes (Dutre and Vandecasteele, 1998) and $\mathrm{Ca}_{3}\left(\mathrm{AsO}_{4}\right)_{2}$
(Vandecasteele et al., 2002) or $\mathrm{NaCaAsO}_{4} \cdot 7.5 \mathrm{H}_{2} \mathrm{O}$ (Akhter et al., 1997) for As(V)-bearing samples. Low leachability of stabilized $\mathrm{As}(\mathrm{V})$ containing wastes compared to other arsenic species (Buchler et al., 1996; Dutre et al., 1999) can be explained by the formation of insoluble $\mathrm{Ca}-\mathrm{As}(\mathrm{V})$ species. On the other hand, the formation of calcium arsenate $\left[\mathrm{Ca}_{3}\left(\mathrm{AsO}_{4}\right)_{2}\right]$ on the surface of hydrating cement particles could retard the hydration of cement (Mollah et al., 1998).

The need for further characterization of the extent of arsenic contamination to better manage the eventual remediation process is apparent. The following objectives were developed to determine the feasibility of using cement-based S/S process for site remediation: (1) characterize the magnitude of arsenic contaminated particles present on the abandoned site; (2) investigate the effect of particle size and admixtures on cementbased S/S process to stabilize arsenic; and (3) determine the long term leaching potential of the stabilized wastes. The leachability of the solidified samples was estimated using the toxicity characteristic leaching procedure (TCLP). The long term leaching potential of arsenic in the $\mathrm{S} / \mathrm{S}$ solidified samples was further observed through a semi-dynamic leaching test. Also, the performance of arsenic S/S treatment was evaluated in conjunction with additive additions, including the use of fly ash from municipal solid waste incinerators. The use of fly ash is particularly relevant since there are over 53000 ton/yr of fly ash generated from municipal solid waste incinerators in Taiwan (TEPA, 2001). The disposal of hazardous fly ash (mainly $\mathrm{Pb}$ ) in conjunction with contaminated arsenic particles is a challenge for engineers working to solving the problems associated with these two types of hazardous wastes.

\section{Materials and methods}

\subsection{Site description}

The copper smelter was constructed in 1969 and operated for 10 years (1971-1981), with a maximum capacity of 10000 ton/yr. The local ores containing iron, gold, copper and arsenic were used as the raw material for copper smelting. The smelting process consisted of a two-stage operation: first stage of a reverbatory furnace at $600{ }^{\circ} \mathrm{C}$ converting $\mathrm{Cu}_{2} \mathrm{AsS}_{4}$ to copper matte $\left(\mathrm{Cu}_{2} \mathrm{~S}\right.$, about $40 \%$ copper purity), followed by a second stage of blowing furnace to increase temperature to $1000{ }^{\circ} \mathrm{C}$ to obtain blister copper (purity of $98 \%$ ). The arsenic sulfide generated would eventually form arsenite oxide $\left(\mathrm{As}_{2} \mathrm{O}_{3}\right)$. The exhaust gas from both furnaces was discharged through three long tunnels (Tunnel A-C in Fig. 1), eventually ended up in a mountain valley. It is unclear when the emission gas was treated in a gravity dust collection chamber. 


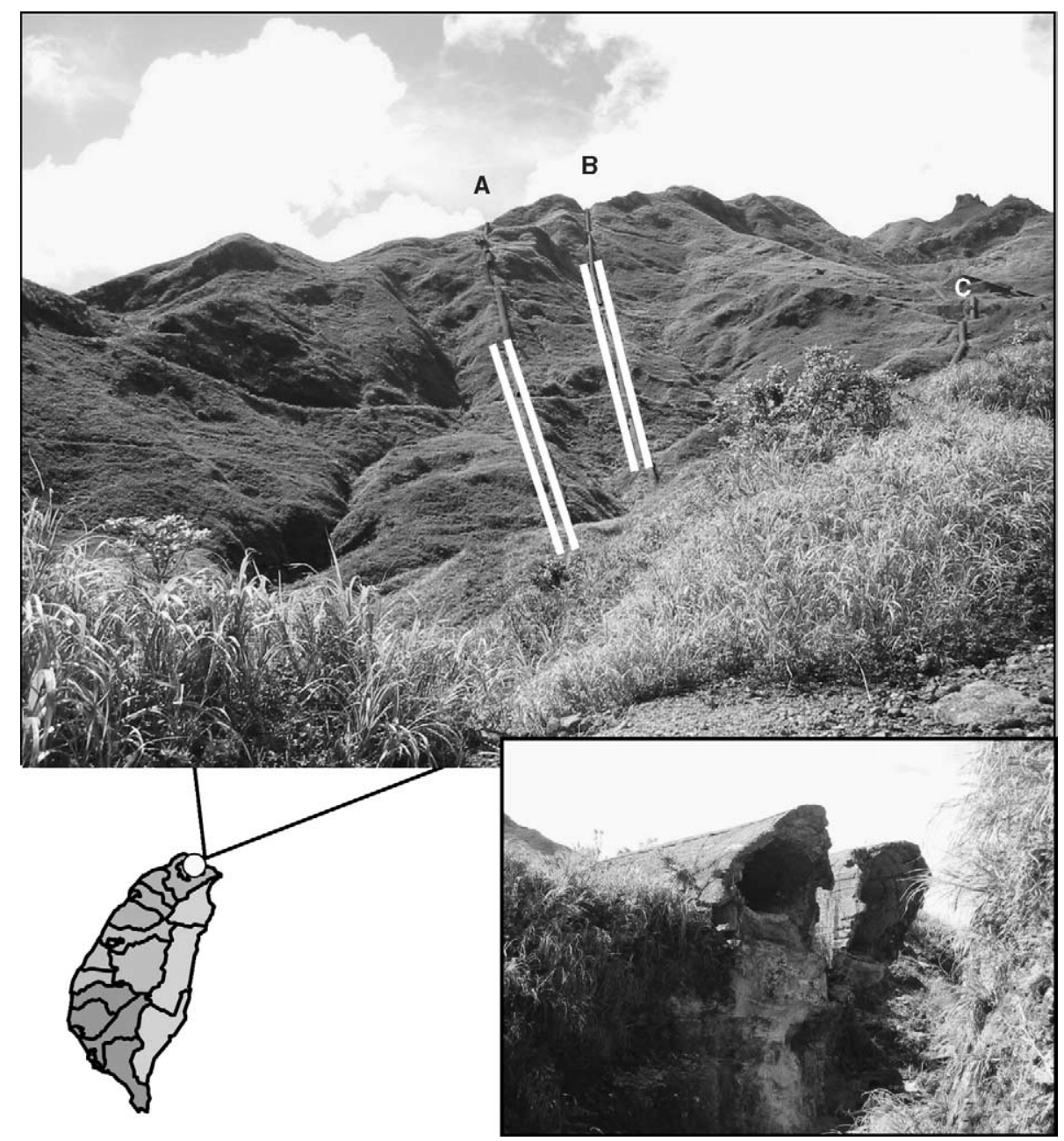

Fig. 1. Site view of tunnels for discharging exhausted flue gas from a copper smelter plant. Samples were taken from the bold-faced sections.

All three flue tunnels were of reinforced concrete semicircular arch type with $2.3 \mathrm{~m}$ wide and $2.5 \mathrm{~m}$ high. A large amount of arsenic oxidant dust from the combustion of the ore component enargite $\left(\mathrm{Cu}_{3} \mathrm{AsS}_{4}\right)$ during the smelting operation was generated, settled down and accumulated inside these gas discharge tunnels. These abandoned tunnels received no maintenance for more than 20 years; corrosion and structural damage occurred at many points (e.g., Fig. 1 insert). The total area of the three tunnels is about 29 ha with the smelter plant area only 3.6 ha.

\subsection{Field sampling}

Because of accessibility problems, no sample was taken from the beginning part $(\approx 50 \mathrm{~m})$ of Tunnel $\mathrm{A}$ and B or the entire Tunnel C. Samples were taken only inside the Tunnel A and B at certain intervals, particularly at sections with slope change and broken areas. A total of 14 locations were chosen for sampling; from 150 to 180 $\mathrm{m}$ above sea level for Tunnel A (Fig. 2) and 165 to $245 \mathrm{~m}$ for Tunnel B (Fig. 3). A hand held global positioning system was used to record the location of each sampling point. In addition, for each sampling point, three samples (top, middle and bottom layer) were collected. The samplers wore Level D personal protective equipment. The samples were stored in $350 \mathrm{ml}$ plastic jars. The physical description of each sampling point, such as depth of sampling point, color and physical appearance was recorded.

The fly ash samples were collected from a nearby municipal solid waste incinerator. This particular incineration plant uses lime spray in semi-dry scrubbers, and hence, fly ash contains a relatively high percentage of $\mathrm{CaO}$. 

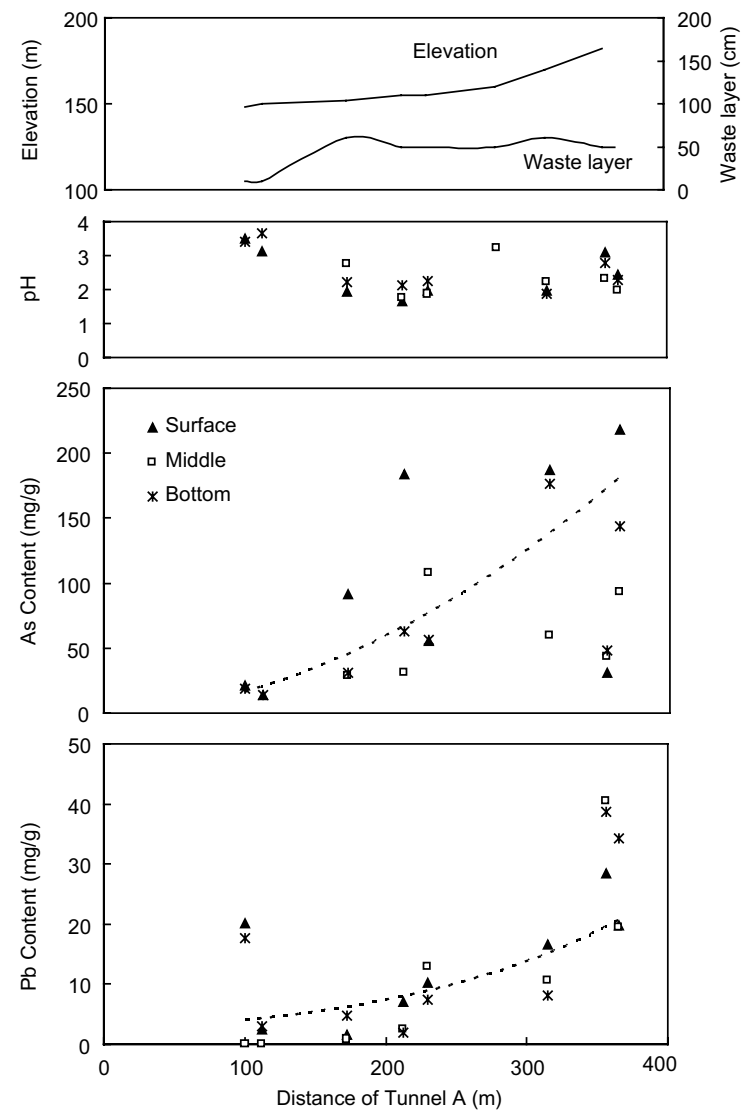

Fig. 2. Contaminated arsenic and lead levels in Tunnel A: dotted lines represent average profile.

\subsection{Samples preparation}

Samples were pre-dried outdoor under shade for 2 days, then dried at $103{ }^{\circ} \mathrm{C}$ for $12 \mathrm{~h}$ for particle distribution analysis. Appropriate dried samples were further milled to less than 1 or $2 \mathrm{~mm}$, dried again and stored in a container for further tests for metal content and subsequent $\mathrm{S} / \mathrm{S}$ tests.

\subsection{Tests}

The dried samples were analyzed through a series of metal sieves with $0.15,1.0,2.0$ and $9.5 \mathrm{~mm}$ mesh to determine the particle distribution.

Only the sample with arsenic concentration about $22.6 \%$ (226000 $\mathrm{mg} / \mathrm{kg})$ was used for subsequent $\mathrm{S} / \mathrm{S}$ tests. Tap water $(10 \% \mathrm{w} / \mathrm{w}$ of waste) and other appropriate chemicals were added to a pre-weighed sample and mixed thoroughly in a kitchen flour mixer (relatively high speed) for three minutes; cement (Type I Portland) and extra water were then added for additional mixing (3 min). In the combination treatment of fly ash and arsenic waste, fly ash was initially mixed with waste
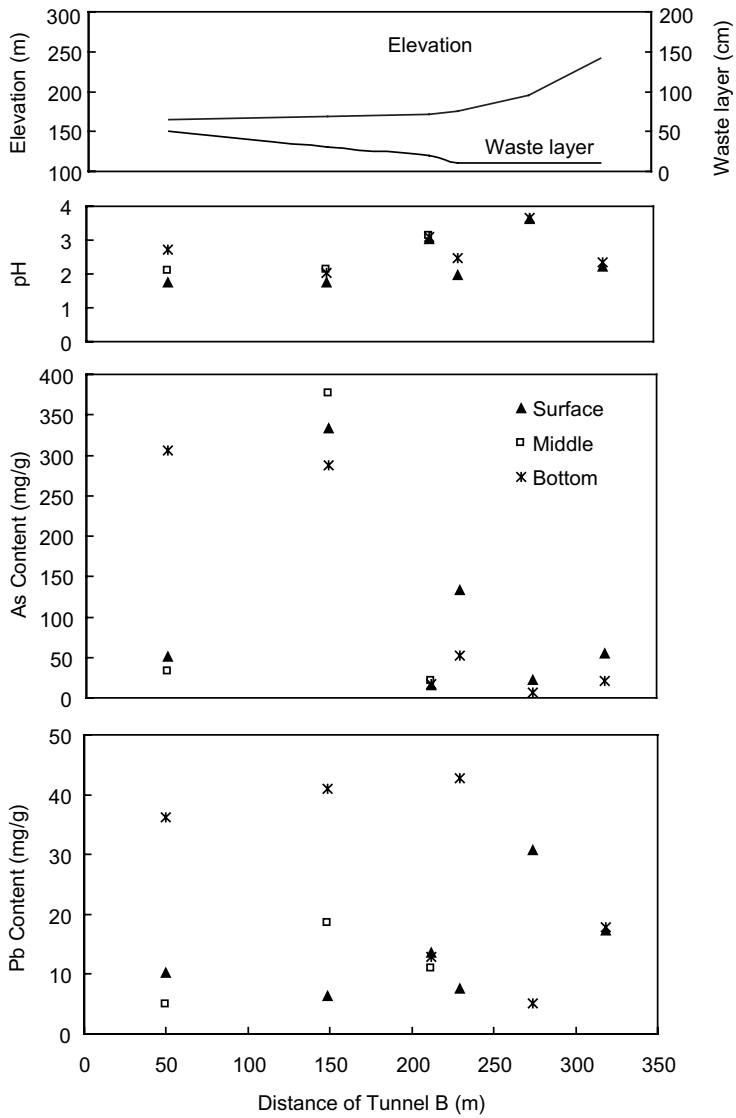

Fig. 3. Contaminated arsenic and lead levels in Tunnel B.

before any additives were added. The S/S sample was then placed into plastic modules $(5 \mathrm{~mm}$ diameter, $10 \mathrm{~mm}$ height) and covered with a moist cloth for curing. After a 5-day curing period, the compression strength, TCLP test, and $\mathrm{pH}$ of the $\mathrm{S} / \mathrm{S}$ samples were determined.

The additives used for the cement binder process include polymer, sulfide and superplasticizers (an enhanced adhesive material based on sulfonated naphthalene) for enhancing S/S performance. Furthermore, the lime was also used as a sole binder to evaluate its effectiveness. The mix ratios of these admixtures are described in the subsequent result section.

\subsection{Semi-dynamic leaching test}

Semi-dynamic tests were performed on different solidified samples to quantify the long term leaching potential of these monolithic samples. The methodology follows those described in the American Nuclear Society standard method (ANS, 1986). Briefly, the solidified wastes were prepared as cylinder pellets with $9.5 \mathrm{~mm}$ diameter and $9.5 \mathrm{~mm}$ height (surface area about 4.25 $\mathrm{cm}^{2}$ ). The ratios of chemical used to the contaminated 
Table 1

Weight ratio of waste to cement and additives used in the $S / S$ treatment in semi-dynamic leaching test

\begin{tabular}{lllll}
\hline & Waste & Fly ash & Cement & Chemical \\
\hline A & 1 & $-^{a}$ & 6 & - \\
B & 1 & - & 6 & 0.15 \\
C & 1 & 4 & 1 & - \\
D & 1 & 4 & 5 & - \\
\hline
\end{tabular}

${ }^{\mathrm{a}}$ None added.

waste for the different tests are shown in Table 1. After curing for 7 days, an appropriate amount of leachant and sample was used (based on the ratio of leachant:surface area $=10: 1$ ) for semi-dynamic leaching tests, without any agitation. Two leachants were employed: deionized water and $\mathrm{pH} 2.88$ acetic acid solution. Some of the tests were performed in triplicates. The liquid content was periodically renewed according to the ANS schedule (from 2 to $1128 \mathrm{~h}$ ). The filtered samples $(0.45 \mu \mathrm{m})$ were analyzed for $\mathrm{Cu}, \mathrm{Pb}$ and As levels.

\subsection{Analyses}

The $\mathrm{pH}$ of samples was tested in a sample/water ratio of 1:1 (20 g of sample in $20 \mathrm{ml}$ deionized water) using a $\mathrm{pH}$ probe. For metal content analysis for arsenic wastes and fly ash, samples were initially digested with nitric acid/hydrochloric acid/hydrofluoric acid, and then analyzed for elemental analyses by inductively coupled plasma spectroscopy (ICP-AES, YuoVen Model 201). The TCLP follows the standard procedures of the US EPA SW846 method 1311 (EPA, 1992). Briefly, $100 \mathrm{~g}$ of samples $($ size $<9.5 \mathrm{~mm})$ were extracted in a $2000 \mathrm{ml}$ glacial acetic solution $(\mathrm{pH}=2.88)$ for $18 \mathrm{~h}$ at $30 \mathrm{rpm}$. The content was filtrated $(0.45 \mu \mathrm{m})$, and filtrate was then analyzed for $\mathrm{Pb}, \mathrm{Cu}$, and $\mathrm{As}$ content in the same ICPAES (EPA, 1996).

Crushed samples were dried, ground to powder and then subject to X-ray diffraction (XRD) analysis (Philips Powder X-ray diffractometer, model PW 1710). The samples were scanned from $5^{\circ}$ to $75^{\circ} 2 \theta$, and the rate was fixed at $0.05^{\circ} 2 \theta / \mathrm{s}$. The measured intensity and $2 \theta$ values were automatically recorded.

\section{Results and discussion}

\subsection{Contamination magnitude}

According to the field sampling record sheet, the depth of the waste accumulated at two tunnels ranges from 10 to $60 \mathrm{~cm}$ depending on the slope of the tunnels (Figs. 2 and 3). As would be expected, the depth of the contaminated layer decreases as the slope increases. From the depth information, It is estimated that total waste quantity for two tunnels is slightly over 700 ton in the studied area (about $40 \%$ of all three tunnels). Due to high temperature smelting process, most arsenic species exist in the form of $\mathrm{As}(\mathrm{III})$, or $\mathrm{As}_{2} \mathrm{O}_{3}$ (Dutre and Vandecasteele, 1995b; NAS, 1997).

The color for most samples was black-grayish; some exhibited light yellowish. The moisture content varied from $10 \%$ to $30 \%$. The $\mathrm{pH}$ values for the arsenic wastes are extremely low, ranging from 1.8 to 3.6 (Figs. 2 and 3). Perhaps, discharged $\mathrm{SO}_{2}$ after a prolonged weathering process may have contributed to low $\mathrm{pH}$ levels. Such low $\mathrm{pH}$ may facilitate the arsenic leaching from the contaminated waste. As(III) may be present as the uncharged arsenous species at such low $\mathrm{pH}$ under reducing conditions, since the $\mathrm{p} K_{1}$ for the arsenite is 8.8 (Barrett et al., 1993).

\subsection{Contaminant level}

Arsenic contaminant levels at different tunnel distances as a function of waste depth (top, middle and bottom layer) are shown in Figs. 2 and 3 for Tunnel A and $\mathrm{B}$, respectively; sample elevation and depth of contaminated waste are also included in these figures for illustration. The arsenic concentrations varied widely from $0.7 \%$ to $37.6 \%$. Based on the limited number of duplicate experiments, the errors in the determination of arsenic content were below $7 \%$.

For Tunnel A data, the arsenic profiles (dotted lines in Fig. 2) except for two places shows an increasing trend in arsenic levels with the tunnel distance. The lead content also shows a similar trend. The reason for the observed pattern is unclear. It is speculated that during the later stage of smelting operation, the installation of air pollution control devices removed a significant amount of arsenic particles and the less particle-containing flue gas would sweep the accumulated particles further away to the far end of the tunnel.

For arsenic levels in Tunnel B (Fig. 3), there is no clear correlation between the arsenic levels and the sample layer as well as the sample distance. At the distance of $150 \mathrm{~m}$ for Tunnel $\mathrm{B}$, there are, however, high arsenic levels (29-38\%). Again, the reason for this observation is unknown. Since this section is just below the steep section (which is after $250 \mathrm{~m}$ with ca. $35^{\circ}$ ), the waste could be accumulated in this flat section. The arsenic leaching by runoff from the top opening and from any collapsed parts of the inclined section would lessen the arsenic levels in those steep sections as shown in Fig. 3 (low arsenic concentrations at distance 250-320 m). The leached arsenic was then carried to the flat junction and, hence, this phenomenon may partially explain high arsenic levels at $150 \mathrm{~m}$.

In all, the arsenic level is highly variable inside these two tunnels. Based on the average arsenic content of $9.2 \%$, there is about 64 ton of arsenic (out of 700 ton waste) present in the studied area. The arsenic levels are 
much higher than those of other arsenic contaminated soils [e.g., $460 \mathrm{mg} / \mathrm{kg}$ (EHD, 2000); 4.2\% (Artiola et al., 1990); up to $3 \%$ (Ongley et al., 2002)] or sediments (up to $0.67 \%$, Ongley et al., 2002), but are still lower than $42 \%$ for fly ash samples from a copper refining process (Dutre and Vandecasteele, 1995b).

The $\mathrm{Pb}$ contaminant profiles are also shown in Figs. 2 and 3. Again, there is a significant variation in concentrations ranging from 0.8 to $42.8 \mathrm{mg} / \mathrm{g}$. High $\mathrm{Pb}$ contents (8-21\%) from copper smelting fly ashes were also reported by Dutre and Vandecasteele (1995b). Copper levels were determined for a few samples, ranging from 50 to $300 \mathrm{mg} / \mathrm{kg}$.

\subsection{Particle distribution}

The sample for each layer (top, middle and bottom) of eight locations was separated into different sizes. The particle distribution with respect to the particle size is shown in Fig. 4. The distribution of particle size does not follow any clear pattern. Nonetheless, the major size fractions for the contaminated waste are located in two regions, $0.15-1$ and $>2 \mathrm{~mm}$. Interestingly, the particle distribution pattern is similar to all samples from these eight locations, relative to its location and its sampling depth. It is noted that for the largest fraction $(>9.5 \mathrm{~mm})$, some of the erosion or corrosion residuals including small stones, broken concrete pieces and steel bars were visible. The arsenic leaching concentration (to be discussed later) in this large fraction is relatively low. Clearly, the initial fine dust particles have been aggregated due to a variety of physical and chemical processes including weathering for the past 20 years. The particle size may play an important role in the subsequent $\mathrm{S} / \mathrm{S}$ process, since coarse particles may hinder stabilization mechanisms, including cement hydration. The subse-

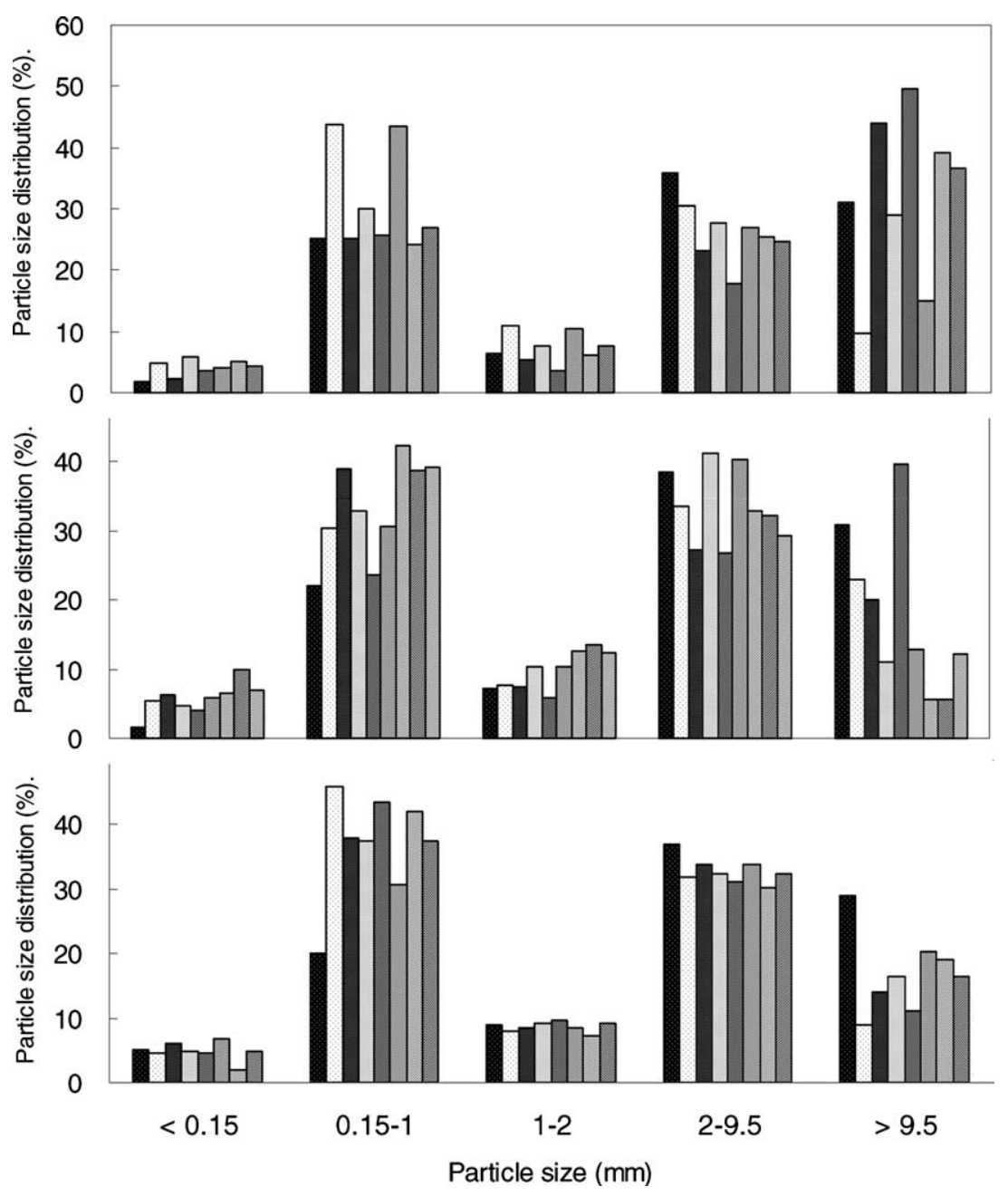

Fig. 4. Particle distribution of contaminated arsenic wastes: each hatched symbol represents different samples. 
quent $\mathrm{S} / \mathrm{S}$ evaluation of the contaminated waste is focused on those samples with particle size less than $2 \mathrm{~mm}$.

\subsection{Leaching potential}

The TCLP arsenic leaching concentrations versus the arsenic content in samples are shown in Fig. 5a. The pH of the leachate varied from 1.9 to 3.0 (from an initial acetic acid $\mathrm{pH}=2.88$ ). There is a clear correlation between the leaching concentration and the initial arsenic amount. The slope in Fig. 5a represents the leaching fraction of the original arsenic content (close to $50 \%$ based on the ratio of leachant to waste $21: 100 \mathrm{~g}$ ). Such a high leaching fraction indicates that arsenic present in the contaminated waste can be easily extracted. As for lead leaching, the concentrations are three orders of magnitude lower (Fig. 5b), despite that fact that the test
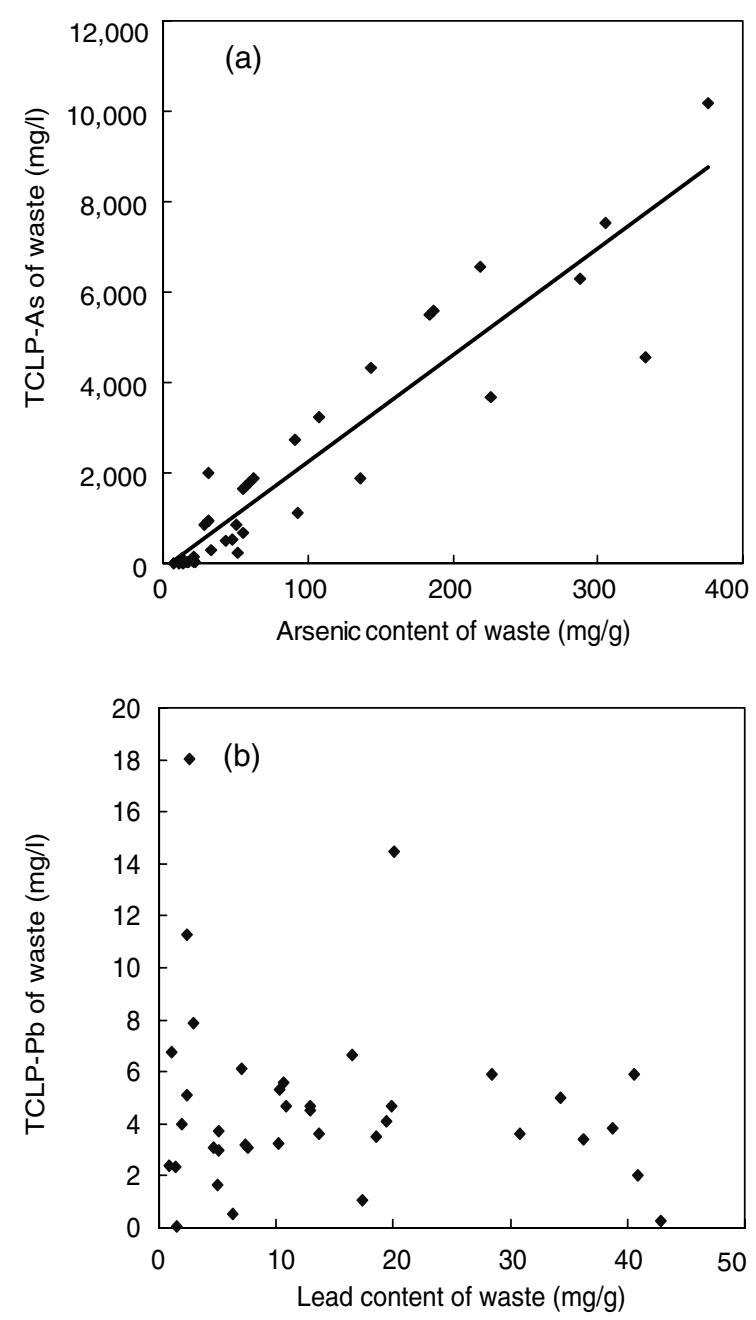

Fig. 5. TCLP leaching concentration versus the metal content (a) arsenic; (b) lead.

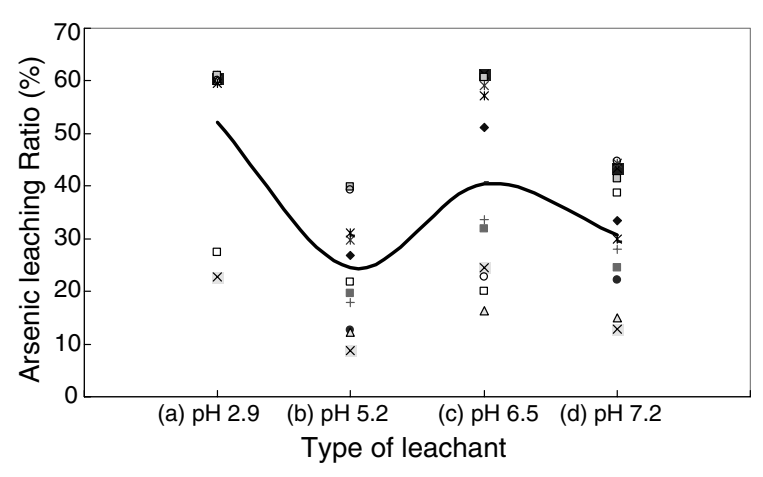

Fig. 6. Arsenic leaching versus type of the leachant (a) acetic acid (initial pH 2.9); (b) acetate (pH 5.2, from $\mathrm{pH} 2.9$ acetic acid solution adjusted with $\mathrm{NaOH}$ ); (c) deionized water (6.5); (d) phosphate buffer ( $\mathrm{pH}$ 7.2).

is performed under low $\mathrm{pH}$ conditions. The fact that arsenic is the most easily leachable element with much lower lead concentrations is also reported by another study of copper smelting fly ashes (Dutre and Vandecasteele, 1995b).

Untreated samples were also subject to three other leachants for observing arsenic leachate concentrations using the same TCLP apparatus: (1) deionized water; (2) phosphate buffer (pH 7.2); and (3) acetic acid pH 2.9 solution but adjusted to $\mathrm{pH} 5.2$ with $\mathrm{NaOH}$. The arsenic leachability as a function of the type of the leachant is shown in Fig. 6. The initial $\mathrm{pH}$ values for these leachants are shown, since the data for leachate $\mathrm{pH}$ were scattered. Again, the leachate $\mathrm{pH}$ of these leachants had been decreased due to the initial low $\mathrm{pH}$ of the contaminated waste (Figs. 2 and 3): phosphate buffer (initial pH 7.2) dropped to 4.8-6.9, acetate from $\mathrm{pH} 5.2$ to $4.0-4.8$, deionized water to 2.3-3.1. The arsenic leachate concentrations should be a function of $\mathrm{pH}$, with the highest concentrations occurring for acetic acid solution $(\mathrm{pH}$ 1.9-3.0). Dutre and Vandecasteele (1995b) also report that the arsenic leaching amount is a function of $\mathrm{pH}$ (lower at $\mathrm{pH} 2$ or 12, but higher at $\mathrm{pH} 6$ ).

The fact that arsenic is easily extracted from a simple leachant solution presents several strategies to handle the waste. The As(III) present in the extracted solution can be recovered, or easily oxidized to $\mathrm{As}(\mathrm{V})$ for further chemical treatment. Alternatively, the cement addition can be delayed after the arsenic is first extracted into aqueous solution to ensure a direct cement hydration with arsenic-containing water. These alternatives for better managing arsenic wastes, however, await further investigations.

\section{5. $S / S$ performance}

Attempts were made to evaluate the amount of cement required and the type of additives needed for the 
effective S/S treatment of the contaminated waste with the same sample containing $226 \mathrm{mg} \mathrm{As} / \mathrm{g}(22.6 \%)$. The sample was separated into three sizes $(<0.15,0.15$ 1 , and 1-2 $\mathrm{mm}$ ) for the evaluation of the extent of arsenic leaching with the different cement dosages. In the present study, the results of compression tests for some 20 samples always far exceed the minimum requirement of $10 \mathrm{~kg} / \mathrm{cm}^{2}$. Thus, the $\mathrm{S} / \mathrm{S}$ performance in the present study is mainly quantified by the TCLP test. The results shown in Fig. 7 clearly indicate that only an extremely high cement addition (cement/sample weight ratio of 6) could meet the TCLP As standard $(5 \mathrm{mg} / \mathrm{l})$. For better illustration, the results for cement/sample weight ratio $>2$ are shown in the insert. Clearly, the sample with a smaller size $(<0.15 \mathrm{~mm})$ would yield a lower arsenic leaching concentration, perhaps due to better interactions between the cement and particles. The high cement dosage not only represents the difficulty in stabilizing arsenic wastes, but also increases the $\mathrm{S} / \mathrm{S}$ cost and eventual disposal volume. Our results are consistent with those reported by Akhter et al. (1997) who used 400\% cement dosage to stabilize 10 wt.\% As(III) in copper smelting fly ash samples. It is noted that although regulatory standards refer to the entire sample consisting of the waste and cement, the contaminant leachate concentrations are apparently diluted due to the extra addition of cement.

Addition of $\mathrm{Na}_{2} \mathrm{~S}$ at $6 \%$ weight fraction at the cement/sample weight ratio of 1:1 indeed reduces the arsenic leachability, or from approx. $1200 \mathrm{mg} / \mathrm{l}$ (average value at cement/sample ratio 1 in Fig. 7) to $800 \mathrm{mg} / \mathrm{l}$ (data not shown). There may be some insoluble arsenic sulfur compounds formed that would retard arsenic leaching. The evaluation of using the fly ash from a

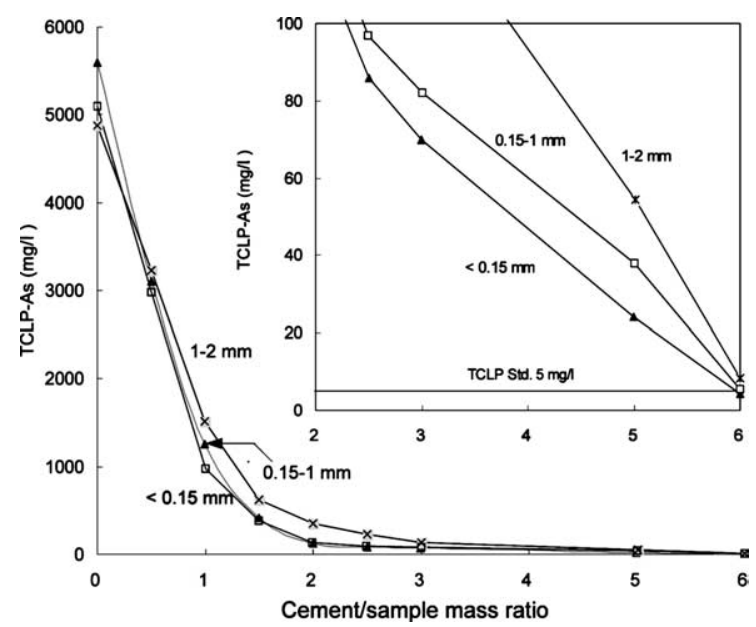

Fig. 7. TCLP arsenic leaching results as a function of cement dosage. The initial arsenic content for the sample is $226 \mathrm{mg} / \mathrm{g}$. municipal solid waste incinerator to reduce the cement dosage in the $\mathrm{S} / \mathrm{S}$ of arsenic contaminated waste was undertaken. The arsenic leaching results of several fly ash additions based on the cement/sample ratio of 1 with or without the addition of an additive (superplasticizer) are shown in Fig. 8. Clearly, at fly ash/sample weight ratio above 3.5 , the arsenic concentrations in the leachate could meet the standard. Although the use of fly ash from power plants as an additive to reduce the cement addition has been widely applied, the use of hazardous fly ash from municipal solid waste incinerators in the $\mathrm{S} / \mathrm{S}$ application is rather limited. In the present study, the S/S performance could be greatly enhanced, or arsenic leaching concentration reduced from 50 to 60 $\mathrm{mg} / \mathrm{l}$ (based on cement/sample ratio of 4.5 in Fig. 7) to less than $5 \mathrm{mg} / \mathrm{l}$. The high $\mathrm{CaO}$ content present in fly ashes during the lime spray in semi-dry scrubbers may have caused the observed enhancement. Incidentially, the $\mathrm{Pb}$ leaching concentrations for all these fly ash samples are always less than $1 \mathrm{mg} / \mathrm{l}$ (The As, $\mathrm{Pb}, \mathrm{Zn}$ and $\mathrm{Cu}$ contents of fly ash were 100, 7000, 18000 and 13000 $\mathrm{mg} / \mathrm{kg}$, respectively). Furthermore, the adhesive compound (superplasticizer) used significantly retards the arsenic leaching. Based on manufacturer's information, the superplasticizer would enhance the dispersion of cement particles, improve the overall of mixing and decrease water usage.

In fact, the addition of raw lime $(\mathrm{CaO})$ at different dosages (lime/sample weight ratio from 0.5 to 3 ) significantly reduced the arsenic leachate concentration to less than $2 \mathrm{mg} / \mathrm{l}$ (Fig. 9). The closely bound calcium arsenic compounds formed after lime addition is certainly responsible for the excellent $\mathrm{S} / \mathrm{S}$ performance with respect to arsenic leaching. A lower dose of $1.3 \mathrm{~g} \mathrm{CaO} / \mathrm{g}$ was also used for arsenic-containing fly ashes (Dutre and Vandecasteele, 1995b). However, there are significantly high $\mathrm{Pb}$ leaching concentrations, or two orders of magnitude higher than As concentrations (Fig. 9) under such high leachate $\mathrm{pH}$ conditions ( $\mathrm{pH}$ about 12.2), due to the

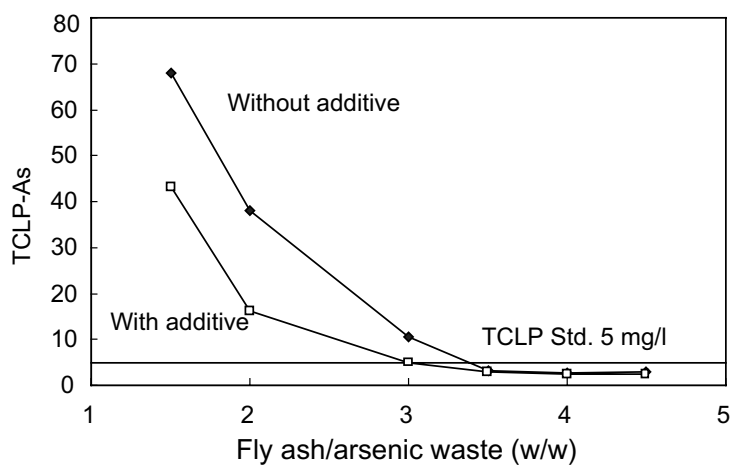

Fig. 8. Effect of the addition of fly ash on S/S performance. The data are based on cement/sample weight ratio of 1 . 


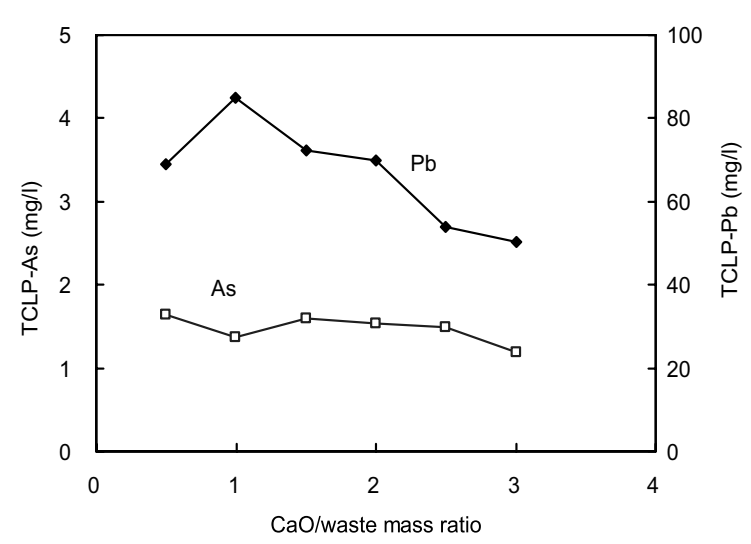

Fig. 9. Arsenic and lead leachate concentrations as a function of lime dosage.

nature of the amphoteric compound, $\mathrm{Pb}(\mathrm{OH})_{2}$ (Mizutani et al., 1996). Dutre and Vandecasteele (1995b) also report higher $\mathrm{Pb}$ but lower As leaching concentrations with the cement/lime solidified matrices of arsenic-containing fly ash from a copper smelter plant. Clearly, in dealing with multi-metal contamination for $\mathrm{S} / \mathrm{S}$ treatment, the best treatment alternative for one particular contaminant may not be optimum for the other. Additionally, the fly ash from copper smelting process may contain a significant amount of antimony (as high as $34 \%$, Dutre and Vandecasteele, 1995b), in addition to arsenic and lead contaminants. Thus, the S/S operation should be optimized based on effectiveness for all concerned contaminants.

\section{6. $X R D$ results}

Four XRD data of raw waste, S/S treatment with cement, lime and fly ash/cement are shown in Fig. 10. The major components for the raw waste are $\mathrm{As}_{2} \mathrm{O}_{3}$ (arsenolite), $\mathrm{PbFe}_{2} \mathrm{O}_{4}$ and $\mathrm{Cu}_{3} \mathrm{AsS}_{4}$ with $\mathrm{Ca}_{3} \mathrm{SiO}_{5}$ and $\mathrm{C}_{3} \mathrm{~S}$ identified in the cemented treated sample and $\mathrm{Ca}(\mathrm{OH})_{2}$ in the lime treated sample. Although most peaks are unidentified due to the lack of data for cementitious As(III) compounds, the comparison does provide somewhat qualitative information. For example, the known $\mathrm{As}(\mathrm{V})$ compounds (e.g., $\mathrm{CaHAsO}_{4}$, $\mathrm{NaCaAsO}_{4}, \mathrm{CaH}_{4}\left(\mathrm{AsO}_{4}\right)_{2}$, or $\mathrm{Ca}_{3}\left(\mathrm{AsO}_{4}\right)_{2}$, etc.) were not identified, hence, it indicates that the arsenic species present in the raw waste is in the trivalent state.

\subsection{Semi-dynamic leaching}

The chemical compositions of four sets of solidified samples for the semi-dynamic testing are shown in Table 1. It is noted that the TCLP arsenic concentrations for all these samples were less than $5 \mathrm{mg} / \mathrm{l}$. Two leachants were used for the $226 \mathrm{mg} \mathrm{As} / \mathrm{g}$ sample: deionized water and acetic acid at $\mathrm{pH} 2.88$. The accumulated $\mathrm{As}$ and $\mathrm{Pb}$ concentrations are shown in Fig. 11 with extremely low copper concentrations $(<0.5 \mathrm{mg} / \mathrm{l})$. Several points are noted. (1) After $200 \mathrm{~h}$, the $\mathrm{As}$ and $\mathrm{Pb}$ concentrations are relatively stable. Thus, there should be no long term stability problems. (2) The samples with a high dosage of fly ash and cement (sample D in Table 1) exhibit the lowest As leaching solution. For lead, the cement alone with the addition of an additive (sample B in Table 1) is the best for yielding the lowest lead concentrations. (3) There is one order of magnitude difference of contaminant leaching concentrations between the deionized water and acetic acid, due to $\mathrm{pH}$ effect. (4) The lead mobility is much less that of arsenic. And (5) The accumulated arsenic concentration for all cases exceed 5 $\mathrm{mg} / \mathrm{l}$. The fact that a periodic renewal of the leachate renders such high cumulated arsenic concentration as compared to the less than $5 \mathrm{mg} / \mathrm{l}$ from TCLP test is difficult to explain.

\section{Conclusions}

A preliminary survey of an arsenic contaminated site from an abandoned copper smelting facility indicates that the waste, located in the three-flue gas discharge tunnels, contained $2-40 \%$ arsenic by weight. The $\mathrm{pH}$ of the waste is extremely low. The XRD evidence indicates that arsenic present in the flue gas mainly exists as $\mathrm{As}(\mathrm{III})$, or $\mathrm{As}_{2} \mathrm{O}_{3}$. The total amount of arsenic contaminated waste is estimated to be 700 ton in the studied area. About $50 \%$ of the particle sizes are less than $2 \mathrm{~mm}$. Arsenic is easily extracted from wastes with a variety of leaching solutions. The implication of this observation is that As(III) present in the extracted solution can be recovered, or easily oxidized to $\mathrm{As}(\mathrm{V})$ for further chemical treatment. Alternatively, the cement addition can be delayed after arsenic is first extracted into aqueous solution to ensure a direct cement hydration with arseniccontaining water.

In order to meet the TCLP arsenic leaching standard of $5 \mathrm{mg} / \mathrm{l}$, an extremely high cement dose is required. The waste with lower particle size having higher specific surface area exhibits somewhat positive effect on the $S / S$ performance. The use of fly ash from municipal waste incinerators, in conjunction with the reduced amount of cement, is able to meet the TCLP standards for arsenic and lead. Thus, the safe disposal of these two types of hazardous wastes is feasible. The use of lime alone could meet the TCLP arsenic standard, but not the lead TCLP standard. In dealing with waste with multi-metal contaminants using $\mathrm{S} / \mathrm{S}$ treatment, the $\mathrm{S} / \mathrm{S}$ operation should be optimized based on effectiveness for all concerned contaminants. 

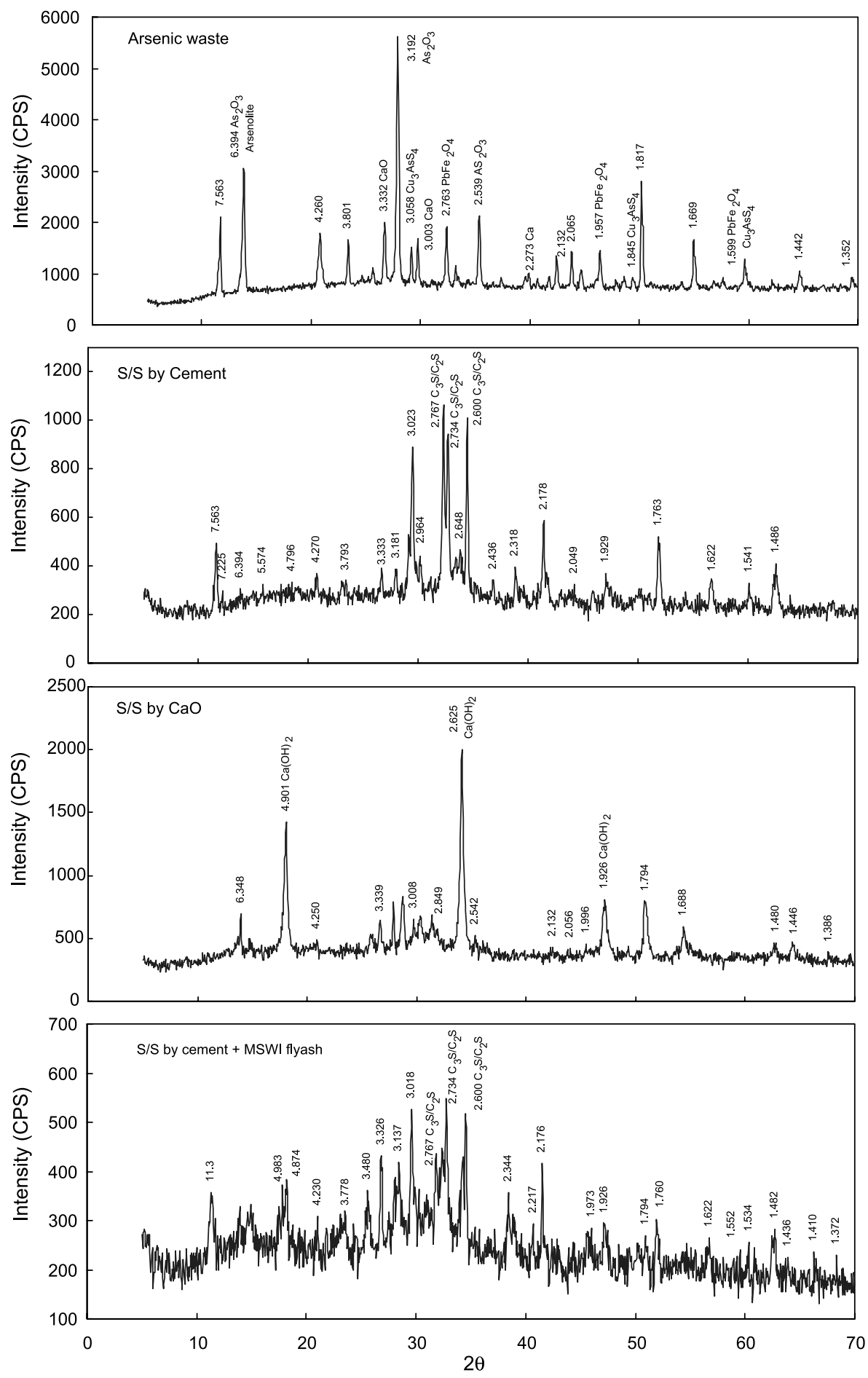

Fig. 10. XRD analyses for four different samples.

The results of semi-dynamic leaching tests of some solidified samples indicate higher accumulated con- taminant concentrations after only a few leachant renewals. 

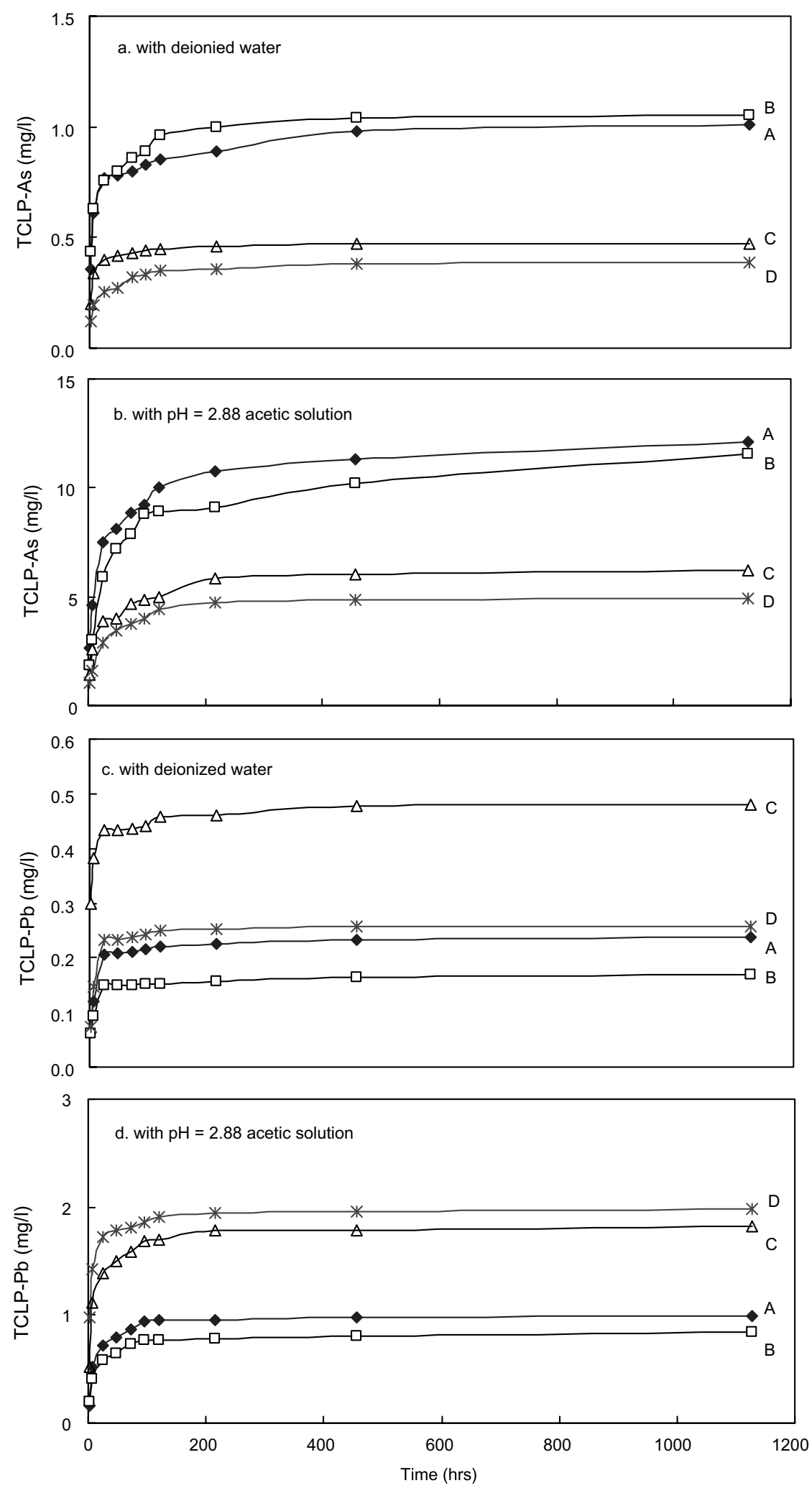

Fig. 11. Accumulated arsenic and lead leaching results from long term semi-dynamic tests. 


\section{References}

Akhter, H., Cartledge, F.K., Roy, A., Tittlebaum, M.E., 1997. Solidification/stabilization of arsenic salts: effects of long cure times. J. Hazard. Mater. 52 (2/3), 247-264.

Akhter, H., Cartledge, F.K., Miller, J., McLearn, M., 2000. Treatment of arsenic-contaminated soils. I: soil characterization. J. Environ. Eng. 126 (11), 999-1003.

ANS, 1986. Measurement of the Leachability of Solidified LowLevel Radioactive Wastes by a Short-time Test Procedure. American Nuclear Society, La Grange Park, Illinois, USA.

Artiola, J.F., Zabcik, D., Johnson, S.H., 1990. In situ treatment of arsenic contaminated soil from a hazardous industrial site: Laboratory studies. Waste Manage. 10 (1), 73-78.

Barcan, V., 2002. Nature and origin of multicomponent aerial emissions of the copper-nickel smelter complex. Environ. Int. 28 (6), 451-456.

Barrett, J., Ewart, D.K., Hughes, M.N., Poole, R.K., 1993. Chemical and biological pathways in the bacterial oxidation of arsenopyrite. FEMS Microbiol. Rev. 11, 57-62.

Buchler, P., Hanna, R.A., Akhter, H., Cartledge, F.K., Thttlebaum, M.E., 1996. Solidification/stabilization of arsenic: effects of arsenic speciation. J. Environ. Sci. Health, Part A 41 (4), 747-754.

Chen, P.Y., Wang, M.K., Hsien, K.L., 2003. Mineral Alterations of Sulfide to Sulfate at Chikushih Gold-EnargirtePyrite Mine in Northern Taiwan. Department of Earth Science, National Taiwan University, Taipei, Taiwan.

Conner, J.R., Hoeffner, S.L., 1998. A critical review of stabilization/solidification technology. Environ. Sci. Technol. 28 (4), 397-462.

Dutre, V., Vandecasteele, C., 1995a. Solidification/stabilization of arsenic-containing waste: leach tests and behaviour of arsenic in the leachate. Waste Manage. 15 (1), 55-62.

Dutre, V., Vandecasteele, C., 1995b. Solidification/stabilization of hazardous arsenic-containing waste from a copper refining process. J. Hazard. Mater. 40 (1), 55-68.

Dutre, V., Vandecasteele, C., 1998. Immobilization mechanism of arsenic in waste solidified using cement and lime. Environ. Sci. Technol. 32 (18), 2782-2787.

Dutre, V., Vandecasteele, C., Opdenakker, S., 1999. Oxidation of arsenic bearing fly ash as pretreatment before solidification. J. Hazard. Mater. 68 (3), 205-215.

EHD, 2000. Vashon/Maury Island Soil Study. Final Report, Environmental Health Division, Public Health-Seattle and King Country, Washington.

EPA, 1992. Test Methods for Evaluating Solid Wastes (SW 846), Physical and Chemical Methods. Method 1311, Toxicity Characteristic Leaching Procedure, Environmental Protection Agency, Washington, DC.

EPA, 1996. Test Methods for Evaluating Solid Wastes (SW 846), Physical and Chemical Methods. Method 6010B, Inductively Coupled Plasma-Atomic Emission Spectrometry, Environmental Protection Agency, Washington, DC.

Federal Register, 2001. National Primary Drinking Water Regulations; Arsenic and Clarifications to Compliance and New Source Contaminants Monitoring; Final Rule. Environmental Protection Agency, 40 CFR Parts 9, 141, and 142.

Ferguson, J.F., Gavis, J., 1972. A review of the arsenic cycle in natural waters. Water Res. 6 (11), 1259-1274.
Fuessle, R.W., Taylor, M.A., 2000. Stabilization of arsenic- and barium-rich glass manufacturing waste. J. Environ. Eng. 126 (3), 272-278.

Ginocchio, R., 2000. Effects of a copper smelter on a grassland community in the Puchuncavi Valley, Chile. Chemosphere $41(1 / 2), 15-23$.

Hwang, Y.H., Bornschein, R.L., Grote, J., Menrath, W., Roda, S., 1997. Environmental arsenic exposure of children around a former copper smelter site. Environ. Res. 72 (1), $72-81$.

Jones, C.A., Inskeeo, W.P., Neuman, D.R., 1997. Arsenic transport in contaminated mine tailings following liming. J. Environ. Qual. 26 (2), 433-439.

Kameswari, K.S.B., Bhole, A.G., Paramasivam, R., 2001. Evaluation of solidification (S/S) process for the disposal of arsenic-bearing sludges in landfill sites. Environ. Eng. Sci. 18 (3), 167-176.

Keegan, T., Hong, B., Thornton, I., Farago, M., Jakubis, P., Jakubis, M., Pesch, B., Ranft, U., Nieuwenhuijsen, M.J., 2002. Assessment of environmental arsenic levels in Prievidza district. J. Exposure Anal. Environ. Epidemiol. 12 (3), 179-185.

Lide, D.R. (Ed.), 1994. CRC Handbook of Chemistry and Physics, 75th ed. CRC Press, Boca Raton, Florida.

Lubin, J.H., Pottern, L.M., Stone, B.J., Fraumeni, J.F., 2000. Respiratory cancer in a cohort copper smelter workers: results from more than 50 years of follow-up. Am. J. Epidemiol. 151 (6), 554-565.

Mariner, P.E., Holzmer, F.J., Jackson, R.E., White, J.E., Wahl, A.S., Wolf, F.G., 1997. Fingerprinting arsenic contamination in the sediments of the Hylebos waterway, Commencement Bay Superdfund Site, Tacoma, Washington. Environ. Eng. Geosci. 3 (3), 359-368.

Matera, V., Hecho, I.L., 2001. Arsenic behavior in contaminated soils: mobility and speciation. In: Selim, H.M., Sparks, D.L. (Eds.), Heavy Metals Release in Soils. CRC Press, Boca Raton, Florida.

Miller, J., Akhter, H., Cartledge, F.K., McLearn, M., 2000. Treatment of arsenic-contaminated soils. I: soil characterization. J. Environ. Eng. 126 (11), 1004-1012.

Mizutani, S., Yoshida, T., Sakai, S., Takatsuki, H., 1996. Release of metals from MSWI fly ash and availability in alkali condition. Waste Manage. 16 (5/6), 537-544.

Mollah, M.Y.A., Lu, F., Cocke, D.L., 1998. An X-ray diffraction (XRD) and Fourier transform infrared spectroscopic (FT-IR) characterization of the speciation of arsenic (V) in Portland cement type-V. Sci. Total Environ. 224 (1/3), 57-68.

NAS, 1997. Arsenic: Medical and Biological Effects of Environmental Pollutants, Commission on Life Sciences. National Academy Press, Washington, DC.

Ongley, L.K.I., Armienta, A., Sherman, L., Adams, D., Concilio, A., Garcia-Escobar, A., Salinas, C., 2002. Arsenic contamination in the soils and sediments of Zimapan, Mexico. Paper presented in the 2002 Denver Annual Meeting, The Geological Society of America, Denver, Colorado.

Oregon, 1999. Soil Cleanup Table, OAR 340-122-045. Oregon Department of Environmental Quality, Portland, Oregon.

Pontius, F.W., Brown, K.G., Chen, C.J., 1994. Health implications of arsenic in drinking water. J. Am. Water Works Assoc. 86 (9), 52-63. 
RTI (Research Triangle Institute), 1998. Toxicological Profile for Arsenic: draft, prepared for US Department of Health and Human Services, Public Health Service, Agency for Toxic Substances and Disease Registry, Atlanta, Georgia, USA.

Shen, Y.S., 1973. Study of arsenic removal from drinking water. J. Am. Water Works Assoc. 65 (8), 543-548.

TEPA, 2001. Study to Minimize the Materials for Solidification of Hazardous Fly Ash. Taiwan Environmental Protection Administration, Taipei, Taiwan.

TPC (Taiwan Power Company), 1994. Feasibility Study of the Arsenic Contaminated Wastes from Exhaust Gas Discharge
Tunnels of a Abandoned Copper Smelter Plant, Taipei, Taiwan.

Vandecasteele, C., Dutre, V., Geysen, D., Wauters, G., 2002. Solidification/stabilization of arsenic bearing fly ash from the metallurgical industry. Immobilization mechanism of arsenic. Waste Manage. 22 (2), 143-146.

Voigt, D.E., Brantley, S.L., Hennet, R.J.C., 1996. Chemical fixation of arsenic in contaminated soils. Appl. Geochem. 11 (5), 633-643.

WDE, 2001. Focus: Tacoma Smelter Plume. Washington State Department of Ecology, Olympia, Washington. 